\title{
Choi Soyoung*
}

\section{Kingship away from Kingdom: The Life of King Ch’ungsŏn (1275-1325)}

https://doi.org/10.1515/asia-2017-0014

\begin{abstract}
King Ch’ungsŏn 忠宣, called Wang Chang 王璋, the 26th King of the Koryŏ Dynasty, was a unique figure among Korean kings. Born to King Ch'ungnyǒl and Qubilai Qa'an's daughter, he also married a Mongol princess, thereby becoming an imperial son-in-law (güregen). During his first reign (1298), he made efforts to reform Koryǒ politics but several months later was deposed by the Mongols and moved to the Mongol capital Dadu 大都. In Dadu, King Ch'ungsŏn served in the royal guard (keshig) for 10 years. In the succession struggle that followed Temür Qa'an's demise in 1307 he distinguished himself in the service of Qaishan (武宗) and Ayurbarwada (仁宗) and rose to power at the Mongol court, and in 1308 was restored to the Korean throne in Koryŏ. Just after the coronation he returned to Dadu and remained there despite Korean and Mongol appeals. When his long sojourn in Dadu provoked criticism, he abdicated for his son but continued to be involved in Korean affairs from his Dadu residence. However, after the death of Ayurbarwada, Wang Chang was banished to Sakya, Tibet, for reasons that are still debated. The new Qa'an Yesün Temür (泰定帝), pardoned him after more than two years in exile. However, even then, he did not return to Koryŏ but ended his life in the Mongol capital, Dadu. Wang Chang's life demonstrates the complicated relationship between the Mongols and their vassal dynasties.
\end{abstract}

Keywords: Koryǒ-Mongol relations, imperial son-in-law, abdication, exile, Tibetan Buddhism, indirect administration

Note: Korean names and words are romanized using the McCune-Reischauer system as defined by the Library of Congress.

Tibetan names and words are romanized using Tibetan Phonetic Transcription; Wylie transliterations are in parenthesis.

*Corresponding author: Choi Soyoung, Department of Asian History, Seoul National University, 1 Gwanak-ro, Gwanak-gu, Seoul 08826, South Korea. E-mail: antirul2@snu.ac.kr 
King Ch’ungsŏn (1275-1325, r. 1298 and 1308-1313, 忠宣王), named Wang Chang (王璋), ${ }^{1}$ was born during the 'Mongol Subjugation period' (1270-1351), ${ }^{2}$ in which the Koryŏ Dynasty (918-1392) was subjugated to the Mongol Empire and Koryŏ politics were under Mongol control. A descendant of a Korean king and a Mongol princess who married into the Chinggisid family, King Ch'ungsŏn ruled Koryŏ mainly from the Mongol capital Dadu, away from the Korean kingdom, and was later banished to Tibet by the Mongols.

This strange career path makes him a unique figure in the history of both Korea and the Mongol Empire. However, he is not widely known outside Korea. In addition, even though there have been excellent studies on King Chungsŏn, these studies examined the political situation around him mainly by Korean and Yuan sources. As a result of it, they overlooked the features of the Mongol Empire period - extensive sharing of information empire-wide which had become possible owing to the fact that the Mongol Empire conquered a huge portion of Eurasia. Therefore, this biography will examine Wang Chang's migration, settlement and banishment through available sources in various languages in the Mongol Empire. In doing so, I hope to present a more holistic view on the life of Wang Chang, which was a product of the Mongol era.

\section{Background: Koryŏ and the Mongols}

After the first conflict with the Mongols, Koryŏ sealed the so called Brotherly Alliance with them in 1219. Being invaded by the Mongols in 1231, Koryŏ, right after signing a peace treaty, moved the capital from Kaegyŏng 開京 to Kangwha Island 江華島 and kept fighting for about thirty years. The Mongols launched six major invasions at tremendous cost to life, leaving Koryŏ unable to offer further resistance. In 1259, the crown prince Wang Chŏn 王倎 (i. e., Wŏnjong 元宗, r. 1259-1274) left to submit to Möngke Qa'an (r. 1251-1259), then campaigning against the Southern Song. Arriving at Liupan Mountain 六盤山, ${ }^{3}$ however, the prince discovered that Möngke had died, and met Qubilai (r. 1260-1294), who

1 Early name Wang Wŏn 王謜.

2 'Mongol poksokki 몽골 복속기' in Korean modern academia, 1270 to 1351 or 1259 to1356. Also called the 'Intervening Period of the Yuan (Wŏn kansŏpki 원 간섭기)'.

3 A mountain range in northern China extending southward from the Ningxia Hui Autonomous Region across the eastern panhandle of Gansu province and into western Shanxi. 
had withdrawn his troops and was proceeding northward. ${ }^{4}$ At the end of that year, when Wang Chŏn was on his way back to Koryǒ, his father King Kojong 高 宗 (r. 1213-1259) died and he returned to Koryŏ with Qubilai’s support as the first Koryŏ king recognized by the Mongols. With Koryŏ-Mongol relations still uneasy, Wang Chŏn was dethroned by a new Koryŏ military power led by Yim Yŏn 林衍 (d. 1270) in 1269, and then restored to throne by Qubilai, who boasted Mongol jurisdiction to decide the ruler of Korea.

It was the envoys of Wang Kŏ 王昛 (i. e., King Ch’ungnyŏl 忠烈王, r. 12741298 and 1299-1308), ${ }^{5}$ son of Wang Chŏn, who first reported the dethronement of the King to the Mongols. On reporting the news, they also requested that Wang Kŏ be married to a Mongol Princess, for reinforcing the king's authority. Qubilai answered that all his daughters had already married and he would discuss the matter with his brothers, ${ }^{6}$ indicating that the Mongols were still deliberating on the best way to rule Koryo. ${ }^{7}$

Five years later, in 1274, Qubilai permitted Wang Kŏ to marry his daughter Qutlug Kelmish 忽都魯揭里迷失 (1259-1297), then fifteen and born to a woman named Asuzhen Khatun 阿速䢐可敦. While the Yuan official history Yuanshi 元 史 did not mention a name corresponding to it, it seems that she was Ūshijīn who was said to be a daughter of Boroghul (d. 1217) in the Persian source Jâmi' al-Tawārīkh by Rashīd al-Dīn (1247-1318). ${ }^{8}$ Boroghul was one of the four steeds of Chinggis Khan and during Qubilai's reign, Boroghul's descendants still

4 This meeting might have been a coincidence, but visiting Qubilai instead of Ariq Böke (1219-1266) brought Koryŏ great benefits. See Kim 2007.

5 His earlier names were Wang Sim (왕심, 王諶) and Wang Ch'un (왕춘, 王賰).

6 KRS: 26. 3a.7-8. The book Koryŏsa, The Official History of Koryŏ, compiled in 1451 by scholars of the Chosŏn Dynasty (1392-1910), Koryŏ's successor state, fills in some blanks in history of the Mongol Empire while it is Koryŏ-self-centered.

7 Koryŏ's resistance even after peace treaty made it difficult for Qubilai to accept the suggestion. When it was advantageous to them, Koryǒ insisted that they had submitted in 1219, which the Mongols seem to have accepted because the concept of 'early submission' was also useful for them. Only when they were on bad terms did the Mongols bring up Koryǒ's resistance. Koh 2014; Masahiko 1998: 244-251.

8 Rashīd al-Dīn said, “Qubilai Qa'an had a khatun who was a daughter of Borûghûl Noyan and her name was Ûshijîn.” JT: 1.173; Thackston 1999: 86. For her name in the genealogy table, see Masahiko 2008: 12. Rashīd al-Dīn mentioned her name as Hûshîjîn in other pages: p. 867, p. 868. Üshijīn/ Hûshîîin means 'woman from the Ūshin (Üüshin)/ Hûshin tribe'. The tribe name was written as $\mathrm{Xu}$ wu shen 許兀㥀 or $\mathrm{Xu}$ shen 旭申 in Yuanshi. Boroghul appears in Chinese sources as Bo'erhu 博爾忽. In addition, she was referred to as Wushizhen 烏式眞 in New History of the Yuan 新元史. (Kim 1989: 169-170) Qutlug Kelmish was installed as Princess Anping 安平 公主 during the reign of Temür Qa'an (r. 1294-1307) and as Princess Qiguo dachang 齊國大長公 主 during Qaishan Qa'an (r. 1307-1311)’s reign. For her see Kim Hyŏnra 2008. 
wielded power, his great-grand son Öchicher (月赤察兒, 1247-1311) being appointed head of a keshig ${ }^{9}$ shift of the Qa'an. ${ }^{10}$

Accepting the marriage request ruled out potential alliance between Koryŏ and the Southern Sung dynasty, and secured Koryǒs active participation in the upcoming invasion of Japan. It is also likely that Qubilai wanted Koryŏ to act as a check against the three uluses $^{11}$ held by Chinggis Qan's brothers in the east. ${ }^{12}$ Qutlug Kelmish brought a rise in Wang Kŏ's status; according to the Koryŏsa, a Mongol envoy to Koryŏ offered a higher seat to Wŏnjong, Wang Kŏ’s father, saying “Now that you are going to marry your son to the Qa'an's daughter, how can I sit on a higher seat than you?"13 In addition, Wang Kŏ sat on the seventh seat among princes, princesses and sons-in-law when he presented himself to Qubilai's successor, Temür Qa'an (r. 1294-1307) in $1296 .{ }^{14}$ The Jāmi’ at-Tawārīkh also mentioned the three sons-in-law of Qubilai, among whom the first was the son of the Koryŏ king, ${ }^{15}$ namely Wang Kŏ, son of Wang Chŏn. Royal marriages between Koryŏ and the Mongol imperial house continued until 1368. While marriage to a Mongol princess was not equally effective in all cases, it was an important qualification for the Korean kings.

The Koryŏ government had to accept a changed political situation, however. After Wang Kŏ's enthronement, the Yuan ordered him to downgrade the Koryŏ kings' temple names and the Koryǒ court's official titles, garment system and terminology. ${ }^{16}$ Wang Kŏ was also appointed Grand Councilor of the Branch Secretariat for Eastern Expeditions (Zhengdong xingsheng, 征東行省), established in 1281 for the expedition against Japan. ${ }^{17}$ These different facets

9 Imperial guards.

10 Chinggis Khan's four steeds were Muqali (1170-1223), Bo'orchu (1162-1226), Chilaun (date unknown) and Boroghul, all of whom were Chinggis Khan's supreme commanders and reportedly supervised the keshig.

11 Realm; people under one ruler.

12 Lee 2003: 21-31.

13 KRS: 26. 9a.1-4.

14 KRS: 31. 5a.7-5b.4; Li 2003: 437-440. Yuanshi shows the status of Korean Kings in the Mongol court before they became royal sons-in-law. In 1270 for example, Qubilai said to Wŏnjong, "Because you submitted late you are ranked under [other] princes. During our Taizu (太祖, Chinggis Ckhan)'s period, Iduqut 亦都護 (Uighur royal title) submitted early, so [Taizu] let him ranked over other princes. Arslan 阿思蘭 (ruler of the Qarluqs a small nomadic Turkish tribe on the upper Irtysh River), submitted later so [Taizu] ranked him low.” (Song (1976) [1370]: 7. 128). Reportedly the Uighur and the Qarluqs submitted simultaneously. For Uighur and Qarluq, see Atwood 2004: p. 563 and p. 448 each.

15 JT: 2. 914; Thackston 1999: 442.

16 KRS: 28. 11a.3-6. See also Chang 1999.

17 The Mongols launched two futile campaigns against Japan, in 1274 and 1281. 
show that Koryǒ Kingship during the period of Mongol suzerainty was multidimensional: Wang Kŏ was a King of a country, son-in-law of the Mongol Qa'an (thus a royal member of Mongol empire) and Grand Councilor of the Branch Secretariat. This complexity of Koryŏ's status was also shown in Jâmi' alTawārīkh saying that Koryǒ (kawlī) is a separate kingdom and at the same time a shing 省 (province), the king of which was called wang. ${ }^{18}$

Before Qutlug Kelmish came to Koryŏ, the Mongol officials whom Qubilai had ordered to escort her, came to install the nomadic tent (qionglu 穹盧) for the princess before her arrival. When it was finished, they warded off evil from the tent by using the oil of white lamb, which was Mongolian custom. ${ }^{19}$ Qutlug Kelmish did not position herself just as a Koryǒ queen, but as a political power that checked Wang Kŏ's rule with an independent administrative unit ( $f u$ 府) and fief in Koryŏ. ${ }^{20}$ Interested in trade like other members of the Mongol royal family, she exported high quality ramie fabric and pine nuts to South China. ${ }^{21}$ Merchants who stayed in the Koryŏ court during Wang Kŏ's reign probably were her ortaq partners. ${ }^{22}$ Many of the bond servants ${ }^{23}$ whom she brought to Koryŏ with her obtained a high position and authority relying on her power. Some of them changed their names and settled in Koryŏ even after the princess died. ${ }^{24}$

18 JT: 2. 909; Thackston 1999: 439. King in Korean is wang 王, which was also the family name of the Koryŏ royal family. About the status of Koryǒ in the Mongol politics, modern scholars' view can be divided into two: first, Koryŏ-Mongol relationship was based upon the tribute system with a variation composed of periodic interventions which took the form of either marital engagements between the two royal families or the Mongols' blatant intervention in Koryŏ politics. (Lee 2009); secondly, since the Koryŏ kings became sons-in-law of the Mongol Empire, it was turned into a fief bestowed to the son-in-law (Kim 2007) or Touxia 投下 (Masahiko 1998).

19 KRS: 89. 1b.3-4. During the Mongol period, Mongol customs such as costumes, foodstuffs and beverages and languages spread over Koryŏ not only by the Mongol nobles, envoys and armies but also Koreans who came back to Koryŏ from the Yuan. From the opposite direction, a lot of Korean people moved to Mongol Yuan and Korean culture also spread among the Mongols. As for the cultural influence of Mongol in Koryǒ and vice versa, see Zheng 2011. Especially for the transfer of distillation technology into Koryŏ, which resulted in the rise of Soju (燒酒, Burned liquor), see Park 2016.

20 KRS: 89, 1b.5-6.

21 KRS: 89. 3b.8-4a.3. For other Mongol queens interested in trade see May 2016.

22 Kim 2008: 86. ortaq is tax-exempt trade, operating mainly with capital of royal members.

23 Qieliankou 怯憐口 in Koryŏsa (also in Yuanshi). From the Mongol ger-ün kö̈ü.

24 While most of them acted high-handedly relying on the princess' power in Koryŏ, they sometimes represented the interest of Koryŏ when they were sent as envoys to the Mongol court. Being her private followers, they were inherited to his son Wang Chang after her death (Koh 2015). 


\section{Wang Chang's career}

Wang Chang, the future King Ch'ungsŏn, was born to her in $1275 .{ }^{25}$ He became crown prince when he was less than two years old, despite having an older halfbrother. The Koryŏsa presents several illustrations of Wang Chang's character, including his affliction on seeing a slave wearing worn out clothes and criticism of a palace servitor who seized a kite from children; Wang Chang had the kite returned. ${ }^{26}$ He did not want to put himself at the mercy of courtiers: when he was 14 years old, being advised by a close courtier that he should be more generous, he rebuked him saying "You people will make me dull and dark, keeping me in the palm [of your hand] and under your control!"27

Wang Chang often visited the Yuan capital Dadu 大都 with his parents. During such visit, when he was three years old, he received from his aunt Kökejin Khatun (d. 1300), Jingim (1243-1285)'s wife and the mother of Temür Qa'an (r. 1294-1307), the Mongolian name Ijir Buqa 益智禮普化, a little bull. From the age of fifteen he spent more time in Dadu than in Koryŏ. Wearing Mongol clothes and hair style, and bearing a Mongol name, he was probably fluent in Mongolian. ${ }^{28}$ Yet, since his childhood he also got Confucian education like other members of ruling families of Koryǒ. When he was 17, being asked what he read, Wang Chang allegedly told Qubilai that he was reading The Comprehensive Mirror in Aid of Governance (Zizhi tongjian 資治通鑑), a famous Chinese mirror for princes, ${ }^{29}$ and that the Chinese emperors Han Gaozu 漢高祖 (BCE 256-195) and Tang Taizong 唐 太宗 (698-649) were wise monarchs. Qubilai asked, “If you compare me with them, who is the best?" Answering evasively, Wang Chang said that he did not know because he was young. ${ }^{30}$ Three years later, in 1295, Temür Qa'an conferred upon him the titles Most

25 When he was born, princes and officials of Koryŏ came to celebrate the birth. At the entrance they were stripped off by the attendant to expel evil things, which was called sebir 說比兒 ceremony in Mongolian. (KRS: 89. 1b.6-9).

26 KRS: 33. 1b.5-7. When an official presented twenty pieces of tiger skin, Wang Chang said, "All of these were taken from the common people by force, incurring their enmity," and made him return them, too. KRS: 33. 2a.3-6.

27 KRS: 33. 2a.8-2b.2.

28 Since Wang Kŏ, Wang Chang's father, Koryŏ kings wore Mongol clothes and hair, although this was not enforced by the Mongols. There were even people crying, seeing that Crown Prince Wang Kŏ was wearing Mongol costumes when he returned from Dadu. (KRS: 27. 27a.6-7)

29 Zizhi tongjian is a consecutive history of China, from 403 BC to 959 A.D., a major reference work in Chinese historiography compiled by the famous Song historian Sima Guang (1019-1086) in 1084.

30 KRS: 33. 2b.9-3a.5. 
Honored, Pillar of State, Crown Prince of Koryŏ and Directorate of the Affairs of Supreme Consultant Office (Yitongsansi shangzhuguo gaoli wangshiziling douqianyishisi 儀同三司上柱國高麗王世子領都僉議使司). ${ }^{31}$

Next year in Dadu, Wang Chang married the Mongol princess Botashiri 寶塔 實憐 (d. 1315), daughter of Kamala 甘麻剌 (1263-1302), Prince of Jin (晉王), ${ }^{32}$ Qubilai's grandson. ${ }^{33}$ She was his fifth wife: before her, he married three Korean wives in Koryŏ and one Mongol wife, Yesujin 也速眞 (d. 1316), apparently of lesser origin, in Dadu. ${ }^{34}$ The Koryŏsa records that Wang Chang presented 81 white horses to the Empress Dowager Kökejin and the latter held a feast for the King with 700 sheep and 500 jars of wine, the Emperor and Empress Dowager attending and many princes, princesses and officials being present. Wang Chang also sent 81 white horses to Kamala, his father-in-law, and gave a banquet. ${ }^{35}$ At the order of Wang Chang, this time the Koreans themselves began a huge construction to set the nomadic tent for the princess even though it was winter time because she was not accustomed to living in non-nomadic palace structures. They set the ground high for the tent and established huge wall around it. During the construction many people died because the ground was frozen. ${ }^{36}$

Next year, in 1297, Wang Chang's mother Qutlug Kelmish died at the age of 38 just after visiting Dadu for her son's wedding ceremony. Wang Chang soon returned to Koryŏ, killing a Korean palace woman (宮人) loved by his father Wang Kŏ along with her favorites and banishing dozens of people close to her under the pretext that they had cursed his mother Qutlug Kelmish and caused her death. ${ }^{37}$ That he accomplished this without his father's permission indicates that he already held supreme power in Koryǒ. Becoming lethargic, Wang Kŏ abdicated in his favor in 1298 and was styled 'Great Former-King' (Taishang wang 太上王). ${ }^{38}$

31 KRS: 33. 3a.6-7.

32 Previously invested Prince of Liang 梁王 and stationed in Yunnan 雲南, Kamala became Prince of Jin 晉王 and moved to Mongolia in 1292. He was also father of Emperor Taiding 泰定帝 Yisun Temür (1293-1328).

33 KRS: 33. 3b.4-6. Morihira Masahiko argues that Mongol princesses married to Korean kings were daughters of princes with expeditionary and garrison roles (出鎭宗王). See Masahiko 2008.

34 Yesujin, was the mother of King Ch'ungsuk (1294-1339), Wang Chang's successor. After her death in 1316, her body was transferred to Koryŏ, where she received the title Ǔibi 懿妃 (Good Queen) (KRS: 89. 16a.8-9).

35 KRS: 33. 3b.5-4a.1.

36 KRS: 105. 27a.5-8.

37 KRS: 122. 18a.1-9.

38 KRS: 31. 21b.2-22b.7. 
Ostensibly 'voluntary', it is certain that the Mongol court was behind this abdication. ${ }^{39}$

As a king, Wang Chang conducted vigorous political reforms, pursuing three specific agendas. First, he abolished the Personnel Office (chŏngbang 政房), which had long abused personnel appointments during the Ch'oe military regime period (1196-1257), that preceded the Mongol-Koryo alliance. Second, he eliminated superfluous posts from the government. Thirdly, he enforced discipline in the capital and elsewhere, elevating the status of inspecting officers and offices. ${ }^{40}$

In the same year, however, the passionate king was suddenly deposed by a Mongol envoy who, seizing the imperial seal and giving it to his father Wang Kŏ, stated that it was by imperial order. ${ }^{41}$ The Qa'an's edict to Wang Kŏ said that because Wang Chang "was dogmatic and his settlements were not fair, many people have been suspicious and afraid." ${ }^{2}$ The Yuanshi mentions that Wang Chang established some offices, including the Bureau for Governance Assistance (zizhengyuan 資政院) on a level equal to that of the Yuan, describing this as 'arrogation'. 43

Another important facet of this situation was Wang Chang's relations with his wife Botashiri. Before marrying her, Wang Chang had married a daughter of the influential Korean vassal Cho In'gyu (1237-1308), Chobi 趙妃(?-?), whom he reportedly loved. 'Jealous' of Chobi, Botashiri sent a letter written in the Uighur script to her aunt the Empress Dowager which said "Chobi put a curse to drive away the King's love from me”. The Empress Dowager subsequently dispatched five Tibetan monks and two Daoists to lift the curse and had Cho In'gyu and his people taken to the Mongol court. ${ }^{44}$ Wang Chang was dethroned soon afterwards. It was said that Wang Chang never visited Botashiri's residence between their marriage and her death. ${ }^{45}$ Even Temür Qa'an reportedly asked a Korean envoy why the king stayed away from Botashiri, receiving the response "How can I know of affairs deep in the bedroom?”, to which the Qa'an agreed. ${ }^{46}$

39 The sources did not mention exactly why he was deposed. However, considering that Wang Kŏ had not got along with his wife Qutlug Kelmish, who had been severely criticizing Wang Kŏ's politics and supported their son Wang Chang, it was probably Qutlug Kelmish who performed a key role in Wang Kŏ's dethronement, though she did not live to see it implemented. See Kim 2008: 87-94.

40 Lee 2008: 271-275.

41 KRS: 33. 16b.5-7.

42 KRS: 31. 23 a.5.

43 Song 1976 [1370]: 208. 4622.

44 KRS: 89. 13b.3-14b.8. Cho In'gyu was exiled to Anxi (安西) and was pardoned later.

45 Lee 2016 a: 173.

46 KRS: 105. 29a.9-29b.3. 
This lack of commitment to the marriage would have been another reason for the dismissal. ${ }^{47}$

Summoned to Dadu, Wang Chang had to stay there for ten years. However, he enjoyed a resurgence by siding with Empress Daji 答己 (d. 1322) ${ }^{48}$ and contributing to the enthronement of her sons Qaishan (Wuzong 武宗, 1281-1311, r. 13071311) and Ayurbarwada (Renzong 仁宗, 1285-1320, r. 1311-1320), after Temür Qa'an's death. The Koryŏsa reports “The King entered the Yuan, serving in the keshig. When Wuzong and Renzong were princes, the King lived together with them and they did not part day or night." ${ }^{49}$ In the 1307 succession struggle after Temür Qa'an's death, Wang Chang helped Ayurbarwada and Daji to defeat Bulughan Khatun (d. 1307) and her rival candidate, Qubilai's grandson Ananda (d. 1307). After Qaishan's enthronement, Wang Chang was invested Prince of Shenyang 瀋陽王 for his distinguished service, and later Prince of Shen 瀋王 in 1310, and "there was no one who gained more favor than him." 50 He was formally appointed also as the tutor of Ayurbarwada, then the Crown Prince. ${ }^{51}$ It would be an exaggeration to say that none gained more favor, but Wang Chang dramatically increased his status in the Mongol court, receiving from Qaishan Qa'an a golden tiger tablet, jade belt, seven treasure belts, 500 liang of gold, 5,000 liang of silver and so on, alongside enormous gifts from the Empress Dowager. ${ }^{52}$ Even though he was a dethroned king, he climbed the ladder of power by winning the trust of the Mongol royal members. Jāmi' al-Tawārīkh mentioned that Qubilai Qa'an married his daughter to the king of Kawli, and his son was one of the Qa'an's intimates (mū'ānis), but he was not the king there, ${ }^{53}$ an accurate description of Wang Chang's status.

47 Lee 2013: 140. From Wang Kŏ (King Ch’ungnyŏl) to King Kongmin (r. 1351-1374), all Korean kings married to Mongol princesses and most of them had marital problems except for King Kongmin and Princess Bothashri (d. 1365). As for Mongol princesses who married Korean kings, see Lee 2003 and Kim 2008.

48 Wife of Dharmapala (1264-1292), Qubilai's grandson.

49 KRS: 33. 16b.7-8. As it was in 1298 that he went to Dadu, and Qaishan went to the Altai to suppress Qaidu (1236-1301) in 1299, Wang Chang would have spent longer with Ayurbarwada. As Ayurbarwada and Daji were exiled to Huaizhou 淮州 in 1305, the period they could have spent together might have been between 1298 and 1305 (Yi 1988: 4-7). Qaidu (1236-1301) was the leader of the Ögödei Ulus and a formidable adversary to the Qa'ans Qubilai and Temür until the beginning of the fourteenth century. See Biran 1997.

50 Yi 1988: 42.

51 His full entitlement was Most Honored, Pillar of State, Grand tutor of Crown Prince, Imperial son-in-law and Prince of Shenyang (Kaifu yitongsansi taizitaifu shangzhuguo fuma douwei shenyangwang 開府儀同三司太子太傅上柱國䭾馬都尉瀋陽王). Yi 1982 [1432]: 2. 23.

52 KRS: 33. 17b.4-6.

53 JT: 2. 909; Thackston 1999: 439. 
Meanwhile, Wang Chang's father, Wang Kŏ, conspired to incapacitate his son, trying to divorce him from Botashiri in order to enthrone another member of the Korean royal family, through marriage to her. ${ }^{54}$ This incident suggests both that Wang Kŏ's abdication for his son was not voluntary and that marriage to a Mongol princess was thought to be a crucial qualification for the Korean kings. Wang Chang, however, overpowered Wang Kŏ, confining him to the Temple of Felicitous Longevity (Qingshousi 慶壽寺) in Dadu..$^{55}$ Even after his release and return to Koryŏ, he had to obey his son's orders from Dadu. On Wang Kŏ's death in 1308 Wang Chang returned to Kaegyŏng and was restored to the throne. Empress Dowager Daji and Crown Prince Ayurbarwada sent envoys to celebrate his re-enthronement. ${ }^{56}$

\section{Remote-control rule of Koryŏ}

After only three months, however, Wang Chang left Koryŏ for Dadu, ruling Koryŏ by 'transferring the edict' (chuanzhi 傳旨)' from Dadu to Kaegyŏng and never returning during his reign. As his stay extended, it placed an enormous financial burden on the Korean government, which had to send him annually - by both sea and land - 100,000 rolls of hemp cloth, $400 \mathrm{hu}$ 斛 of rice and immeasurable supplies. ${ }^{57}$ Koryŏ's courtiers petitioned him to return saying that it was difficult for them to handle the many affairs when the king was 4,000 li far away from the Koryŏ court. ${ }^{58}$ In addition, because the King dwelled in Dadu, a number of his attendants had to stay serving him, leaving their home country. ${ }^{59}$ The frequent contacts between the Mongol and Koryŏ courts even led to an increase in the status of skilled interpreters of Mongolian, who rose to unprecedented high ranks in the Koryŏ court. ${ }^{60}$ Their power, however, was gradually diminished as Koryǒ

54 KRS: 89. 15a.2-7.

55 It was the shrine temple of the Yuan royal family.

56 KRS: 33. 20a.9-20b.1; 21b.6-7.

57 In addition to the fixed levy, officials staying in Dadu often visited Koryŏ to collect more supplies for Wang Chang, delivering the King's order 'by oral instruction' without official documents, which crippled Koryŏ financially. (KRS: 104. 4b.9-5a.1)

58 KRS: 33. 28b.2-29b.3. Koryŏ was closer from Dadu than other political entities of the Mongol Empire. However, it is inevitable that without the king the Koryŏ court went uncontrolled and people suffered from heavy revenue to meet the King's cost of stay at the Mongol capital.

59 KRS: 104. 48a.1.

60 Cho In'gyu, father of Chobi, was also a Mongolian interpreter who won the trust of both Mongol and Koryŏ rulers, by which he rose to power. As for the interpreters during this period, see also Lee 2015. 
officials also learned to speak Mongolian to grasp Mongol political issues, which was one of the distinct features of Koryŏ court during Mongol period. ${ }^{61}$

When Qaishan died in 1311, and Ayurbarwada ascended the throne, Wang Chang enjoyed the favor of the Qa'an and Empress as before. In 1312, however, the Qa'an and Empress Dowager also ordered him to return to Koryŏ, probably because he was leaving his country lordless for a long time. Wang Chang declined the order, under the pretext that if he returned to Koryŏ during the peak farming season, it would damage agriculture ${ }^{62}$ because farmers would be conscripted to serve him on his way. This was accepted. After being permitted to prolong his stay, he asked the famous writer Cheng Jufu 程鉅夫 (1249-1318) to engrave his previous endowment of The Complete Collection of Buddhist Sutras (Dazangjing 大藏經) to Qingshou Temple on a stele. He also visited Koryŏ Temple (高麗寺, Ch. Gaolisi) ${ }^{63}$ at Hangzhou and prayed for Ayurbarwada and the Empress Dowager in $1313 .{ }^{64}$

When pressed again to return, Wang Chang chose to abdicate, conferring the throne on his son Wang Do 王壽 (i. e., King Ch'ungsuk 忠肅王 r. 1313-1330, 13321339) ${ }^{65}$ rather than leave Dadu. Despite this abdication, he was no longer allowed to stay, perhaps due to Ayurbarwada's general policy of limiting the power of blood princes and imperial sons-in-law in his court. ${ }^{66}$ Wang Chang returned to Koryŏ with an enormous retinue dispatched by the Qa'an and the Empress. ${ }^{67}$

After returning to Kaegyŏng, Wang Chang conducted much bigger Buddhist rituals than in Dadu: The Koryŏsa records of his activities during this period all concern Buddhism. He served two thousand monks meals every day over five days to perform a special Buddhist ceremony, Gathering of Ten Thousand Monks (wansenghui 萬僧會), in a palace which he subsequently endowed as the

61 Lee 2014: 397-398.

62 KRS: 34. 3b.8-4a.1.

63 Originally Huiyin Temple 慧因寺 situated at Hangzhou, Zhejiang and established in 927. Because the famous Ǔich’ŏn 義天 (1055-1101), a member of the Koryŏ royal family who became a monk stayed there, it was called Koryŏ Temple.

64 Chang 1999: 716.

65 Wang Do was born to Yesujin, which made him wield much less power than his father, whose mother was a daughter of Qubilai. For Yesujin, see above and note 34.

66 Some scholars suggested that on Ayurbawarda's enthronement the political status of Wang Chang got worse, thereby encouraging him to return to Koryŏ. (Kim 1996: 317-318. Cf. Hidehiro 1959: 537; Yi 1988: 48) It also seems that it was a general policy of the Mongol Empire for princes and sons-in-law not to stay long in the court. During Qubilai's reign, when Crown Prince Wang Chang was staying in Dadu with his father Wang Kŏ, a high official said to Wang Chang, "The Emperor ordered the princes and sons-in-law to go back to their countries, which means he wishes they should defend and secure their armies and people.” (KRS: 123. 29b.2-5)

67 KRS: 34. 10a.1-6. 
Minch’ŏn Temple (旻天寺) ${ }^{68}$; the Koryŏsa compilers lamented that there was no one to stop him. ${ }^{69}$

Notably, after finishing the rituals, Wang Chang ordered an office in Koryŏ to report all ceremonies to the Mongol court in detail. ${ }^{70}$ Thus, it seems that he conducted the Buddhist rituals not out of blind faith in Buddhism but for showing devotion to the Mongol rulers. ${ }^{71}$ Indeed, upon his return to Dadu with this report, stressing that he had prayed for the Qa'an's and the Empress Dowager's longevity and that the Koryŏ people anticipate their long life, he was allowed to stay there longer. While perhaps not the only reason, this report was probably the principal factor behind his permission to stay in Dadu. Three years later (1316), he passed the title of Shenwang 瀋王 to his nephew, too. ${ }^{72}$

At the beginning of the contact between Koreans and the Mongols, it was totally alien for Koryŏ that the king in person would visit a foreign court. For example, in 1241, during Ögödei's reign, the Koryǒ king was pushed to visit and have an audience with the Qa'an. Koryŏ sent a fake prince, a relative of the king, named Wang Chun (王綧, 1223-1283) with other sons of nobles. ${ }^{73}$ While Koryŏ did not consider it important, Yuan records repeatedly mentioned Wang Chun's submission ${ }^{74}$ because the Mongols thought it was a critical juncture in KoryǒMongol relations that the ruler came to them in person. A Persian source shared the same perception, saying: During that same year they took innumerable turqaqs and keshigs from Solangqa and sent them to the Qa'an with Ōng Sū (i. e. Wang Chun) at their head (muqaddam). ${ }^{75}$ From the Mongols' perspective, his audience with the Qa'an represented the real submission of Koryǒ. In addition,

68 KRS: 34. 12b.5-13a.3. Buddhism was introduced to Korea from China under the Former Qin dynasty 前秦 (315-394). The founder of Koryŏ, Wang Kŏn (877-943), promoted Buddhism as national religion. In the latter half of Koryŏ, however, Buddhism was on decline, although National Preceptor (國師) and Royal Preceptor (王師) were still appointed independently. For Koryŏ Buddhism, which apparently was not under the control of Yuan's Bureau of Tibetan and Buddhist Affairs (宣政院), see Vermeersch 2008.

69 KRS: 33. 30a.7-30b.1.

70 KRS: 34. 17a.1-7.

71 Pyŏn 2003: 198; Kim 2011: 81.

72 KRS: 34. 7a.9-7b.1.

73 KRS: 90. 7b.3-6. Actually Wang Chun was the precursor of Wang Kǒ and Wang Chang, in marrying to a Mongol princess and staying at the Mongol court. Her status was high, enough to make Hong Pogwǒn (洪福源, 1206-1258), a man of influence who even looked down upon the Koryŏ king, to kneel upon his knees, saying she was a member of royal family (皇族) (KRS: 130. 4b.8-5a.4).

74 YS: 2. 37; 120. 2968; 149. 3536; 154. 3628.

75 Thackston 1999: 313. In Jāmi' al-Tawārīkh, Sōlāngqa sometimes referred to Koryǒ, sometimes the north of Koryǒ. This article says that it was in 1234 that Wang Chun went to the Mongol 
as late as the reign of Wongjong, Wang Chang's grandfather, when Qubilai demanded that Wŏnjong should come for a personal audience in 1264 for celebrating his victory over his brother Ariq Böke, most of the Korean courtiers "harbored suspicion that he (Wŏnjong) would meet mishap" and could not decide what to do. Therefore, Yi Cangyong 李藏用 (1201-1272), Vice Director of Secretariat and Manager of Affairs (中書侍郎平章事), who alone favored the idea, had to pledge that if the King met with trouble, he would put up with the execution of all of his relatives. ${ }^{76}$ Two generations later, however, Wang Chang tried to stay at the Mongol capital even by abdicating from his throne.

Returning to Dadu, he made a hall in his residence into 'the Hall of the Development and Expansion and the Basis of Virtue' (Jimeijide Hall, 濟美基德堂) where he meditated and read Buddhist sutras:

After the King abdicated two thrones, he stayed in the capital and refused audiences under the pretense of illness. He named the residence Jimeijide Hall and after cleaning it, locking the door and burning incense, he was kneeling all day long. Even though he had been a heavy drinker, he did not drink alcohol at all. He kept just one horse in his stable and was not interested in music and falconry at all. He enjoyed only Buddhism and donated one of his palaces to turn into Minch'ŏn Temple. [...] He invited Tibetan monks for sutra translation and Buddhist initiation. ${ }^{77}$ A year never passed without those activities, so people remonstrated against it, but he did not listen and liked it still more. ${ }^{78}$

In addition, he constructed another hall, possibly identical with the former, named 'the Hall of Ten Thousand Volumes' (Wanjuandang 萬卷堂), where he invited noted Confucian scholars for discussions. ${ }^{79}$ He ordered the Korean scholar Yi Chehyŏn 李齊賢 (1287-1367), who became his closest courtier, to come to him and they associated with renowned Chinese literati such as Yao Sui 姚燧 (1238-1313) ${ }^{80}$ and Zhao Mengfu 趙孟煩 (1254-1322). Especially,

court with turqaqs and keshigs, while Koryŏsa mentioned that it was in 1241. Detailed discussion on this article, see Kim 2005: 65-66.

76 KRS: 102. 23a.8-23b.3.

77 When he was in Koryŏ, he also had invited Tibetan monks Bahasi 八哈思 according to Koryŏsa. (KRS: 33. 9b.6) It is certain that this word is baqshi, the designation for Buddhist priests during Mongol period, which was originally from Chinese and then Turkic. He got Buddhist initiation together with Bothashri, which was a common practice among Mongol royal members. (KRS: 33. 12b.5-6; 8-9)

78 Yi 1982 [1432]: 2. 24.

79 KRS: 34. 6b.4-6. As for Jimeijide Hall and Wanjuan Hall, see Kim 2011: 59-95.

80 Because Yao Sui died in 1313, they might have associated with each other before the Wanjuan Hall was open. They were not on good terms with each other from the beginning. Yao Sui's Yuanshi biography recorded that the Korean Prince of Shenyang 瀋陽王, father and son continuously became sons-in-law of imperial family and socialized with courtiers pumping 
Wang Chang introduced a young poet and painter Zhu Derun 朱德潤 (1294-1365) to the Mongol court and the latter left many writings on Wang Chang and Yi Chehyŏn. ${ }^{81}$

Meanwhile, Wang Chang continued to conduct the affairs of Koryŏ from behind the scenes, entrusting the personnel administration of Koryǒ to his own favorites. Upon returning from Koryŏ to Dadu after his abdication in favor of his son, Wang Chang ordered his Korean favorites to survey the land in Koryŏ. When those officials committed irregularities during this process, the current king Wang Do was unable to punish them because they were his father's favorites. ${ }^{82}$ Wang Chang even appointed his nephew Wang Ko 王暠 (d. 1345), a rival of king Wang Do, as crown prince, in order to keep the latter in check.

Wang Chang's public image was, however, that of a sincere Buddhist. At the beginning of Ayurbarwada's reign, when the new Qa'an suggested that Wang Chang be appointed Grand Councilor, he refused arguing that he had renounced the Korean throne in favor of his son due to incompetence, and added: "I am old and my only duty is worshipping Buddha and praying for your majesty's long life." Ayurbarwada smiled and said that he knew well that Wang Chang had long kept himself away from politics. ${ }^{83}$ He participated in religious activities, especially for the Qa'an and Empress Dowager, visiting a sick disciple of Phagpa ('Phags pa, 八思巴 1239-1280) ${ }^{84}$ by the order of Ayurbarwada in $1314^{85}$ and guiding Empress Dowager Daji during her pilgrimage to Mount Wutai 五臺山 in $1316 .{ }^{86}$ In 1319, he received permission and went on pilgrimage to Mount Putuo 普陀山, ${ }^{87}$ one of the four sacred mountains in Chinese Buddhism. After that, he visited the Chan Buddhist master Zhongfeng Mingben 中峰明本 (1263-1323) in Hangzhou, looking up to him as his spiritual mentor. In addition, he endowed several copies of The Complete Collection of Buddhist Sutras taken from Koryŏ to Yuan temples. ${ }^{88}$ However, despite these enthusiastic participations in Buddhist

their wealth (傾貨結朝臣). Yao Sui sneered at Wang Chang saying that [Koryŏ] was a small vassal country and only valued wealth. For Yao Sui, see Song (1976) [1370]: 174. 4057-4059).

81 For Zhu Derun, see Chang 2011.

82 KRS: 108. 12a.6-12b.3.

83 Yi 1982 [1432]: 2. 25.

84 Drogön Chögyal Phagpa ('Gro-mgon chos-rgyal 'phags-pa) from the Sakyapa sect of Tibet, Qubilai's Imperial Preceptor and most respected among the monks, created the Phagpa script at the Qa'an's order. See Chen 1992 and Petech 1993. For the title Imperial Preceptor, see Petech 1990: 36-37.

85 Shi 2000 [1341]: 22. 461.

86 KRS: 33. 27b.8-9; Kim 2011: 79. Mt. Wutai, in Shanxi Province.

87 Located on an island southeast of Shanghai, Zhejiang province. It is a renowned site of Chinese Buddhism, allegedly the residence of the Bodhisattva Avalokitesvara (Guanyin).

88 For Wang Chang's Buddhist activities, see Chang 1999: 729-733. 
activities, he voiced objection to building shrines for Phagpa. At the beginning of Ayurbarwada's reign, the court considered to establish for the Tibetan monk, the first Imperial Preceptor Phagpa a shrine as great as that for Confucius. Wang Chang alone opposed this, saying that Phagpa had the merit of inventing script, but this was not comparable to Confucius' great virtue as the master of all kings. The Koryŏsa added that even though he alone objected it, all those presents agreed with him in their minds. ${ }^{89}$

\section{Banished to Tibet}

In 1320, Ayurbarwada's death and the enthronement of Shidebala (r. 1320-1323) changed Wang Chang's situation. Ayurbarwada and Daji broke their promise to Qaishan and appointed the former's son, Shidebala, as crown prince. After Ayurbarwada died, Shidebala ascended the throne but there was a division between the new Qa'an and his grandmother Daji. In the same year, with the conspiracy of Daji and her close associates against Shidebala having been uncovered, the new Qa'an executed them without trial. According to the Koryŏsa, wanting to avoid trouble, in 1320 Wang Chang asked the Qa'an to let him go to Jiangnan 江南 to visit royal shrines and burn incense. He got permission, but was arrested in a temple in Jiangnan by Shidebala's order.

In the sixth month [of 1320], when Wang Chang and his company arrived at Jinshan Temple 金山寺, ${ }^{90}$ envoys from the Emperor came, surrounded him and drove him forward saying that he had an urgent recall order. All the attendants fled. In the ninth month, the king reached Dadu and the Emperor ordered the Central Secretariat to convey the King to Koryŏ and keep him in one place. The King did not leave, however, but hesitated. In the tenth month, the Yuan Emperor imprisoned the King in the Ministry of Punishments (刑部), tonsured his head and incarcerated him in a temple in Dadu. In the twelfth month, on wu shen 戊申 day, the Emperor exiled the king to Sakya (Sa skya, Ch. Sasiji 撒思吉), Tibet. $^{91}$

Shidebala banished Wang Chang ostensibly so that he could study Buddhist sutras. $^{92}$ Koryŏ sources suggest that he was exiled due to false charges from Yim

89 KRS: 34.6b-7a.2. Later, when Wang Chang was exiled to Tibet, Phagpa shrines began to be built. For the relations between the Phagpa shrine and Wang Chang, see Li 2010; Ma 2013.

90 In modern Zhenjiang 釱江, Jiangsu Province 江蘇省.

91 KRS: 34. 7b.4-8a.1. wu shen. 'Sakya (sa skya)', sometimes sasijie 撒思結 in other Korean sources; sasijia 薩斯迦 in the Yuan sources, meaning 'grey land', refers to the hometown of the Sa skya pa sect, from which the Yuan Imperial Preceptors originated, which was located southwest of Lhasa.

92 KRS: 35. 3b.6-8. 
Bayan Tegus 任伯顔秃古思 (d. 1323), a slave from Koryŏ who castrated himself and went to the Mongol court, finding favor with Ayurbarwada when he was still crown prince. Committing many outrages and seizing land, he behaved disrespectfully to Wang Chang and was beaten at Wang Chang's orders, being forced to return the lands to their original owners. Because of this, he harbored a grudge against Wang Chang and as soon as Ayurbarwada died, bribed a son of the chief councilor (and crown-maker) Temüder 鐵木迭兒 (d. 1322), ${ }^{93}$ and slandered Wang Chang. ${ }^{94}$

We do not know, however, what exactly the false charge was about or why Shidebala exiled Wang Chang to Tibet. Modern scholars suggested several reasons: First, Shidebala was in conflict with Daji. The fact that Wang Chang was the latter's favorite would have been the reason of exile. He might have even been involved in Daji's plot against Shidebala in 1320. Second, some Mongols and Koreans wanted to abolish the Koryŏ Dynasty and make Korea a regular Yuan province. Banishing the Koryŏ king to a remote place could have facilitated this. ${ }^{95}$ Third, another possible background for the exile was Shidebala Qa'an's irascibility and sensitivity to 'Lèse-majesté affairs', owing to his lack of legitimacy. ${ }^{96}$

Wang Chang went to Tibet with eighteen followers, some of whom even tried to assassinate him, complaining on the tough road to Tibet. In July 1321, Wang Chang wrote a letter to his courtiers in Xifan (西蕃) ${ }^{97}$ lamenting his fortune and urging them to appeal to the Qa'an to pardon him and return him as soon as possible. $^{98}$ The Koryŏ court sent travel expenses for Wang Chang, an official even

93 For Temüder, the Chief Councilor of the Central Secretariat on Shidebala's enthronement, see Cho's article.

94 KRS: 122. 19a.4-19b.3.

95 Even though the politics of Koryŏ was at the hands of the Mongols, it bore significant difference whether Koryǒ ruling house existed or not. "The arguments to create a new Branch Secretariat 立省論” upon Koryǒ was brought up in Yuan court several times, having different shapes and agendas, all of which failed. As for this argument, see Lee 2013.

96 Ch'oe 2015: 311. Even though we do not know what the exact allegation was, it seems that Wang Chang was charged with a capital crime. In the Koryŏ officials' appeal to Baiju 拜住 (1298-1323), Chief Councilor to the Central Secretariat, they stated that Baiju had saved Wang Chang's life, merely exiling, rather than killing, him. (KRS: 110. 29. b2-5) The Koryŏsa omission of the charge, even while claiming it was a false accusation, is perhaps because it was too heavy to record. The fact that two of Wang Chang's favorites committed suicide on the news of his arrest also suggests a very serious charge. (KRS: 124. 8a.4-8)

97 Amdo. Both Chinese and Korean sources usually referred to Tibet as Tufan 土蕃/吐蕃, sometimes Xifan. But in this sentence Xifan indicates Amdo/Domei (mDo smad 秃思麻), one of the three traditional regions of Tibet, encompassing modern Qinghai and parts of Gansu and Sichuan.

Wang Chang referred to the village name as Duzhili (獨知里), probably a post town in Amdo. 98 KRS: 35. 6b.3-7a.1. 
contributing him his own gold. ${ }^{99}$ Wang Chang arrived at Sakya in the tenth month that year. Tibetan sources never mentioned this abdicant king's exile to Tibet.

It happened that the Imperial Preceptor 帝師 of Shidebala Qa'an, Kunga Lodrö Gyeltsenpel Sangpo (1299-1327) ${ }^{100}$ came back from Dadu to Sakya to take his full ordination in 1322, just after Wang Chang's arrival to Tibet. ${ }^{101}$ According to the Koryŏsa, Wang Chang wrote again to his courtiers that the Emperor reportedly allowed him to return and it could have been from the Imperial Preceptor that he received this information even though it was false. A Sakyapa source mentioned that in 1322 a Great Dharma Wheel (Chos 'khor chen po) ceremony for Phagpa was held in Sakya, ${ }^{102}$ which seems to be supervised by the Imperial Preceptor and his father Danyi Chenpo Zangpo Pal (bDag-nyid chen-po bzang-po dpal, 1262-1324), who was the abbot of Sakya. ${ }^{103}$ Furthermore, after Wang Chang was exiled to Tibet, Phagpa's shrine began to be built in Yuan, leading some modern scholars to suggest the exile might have been related to his opposition to the constructions of shrine. ${ }^{104}$ In addition, it is certain that the last Southern Song emperor, Zhao Xian (趙顯, 1271-1323), who had been exiled to Tibet on the pretext that he should study Buddhism by Qubilai was also at Sakya when Wang Chang arrived there. ${ }^{105}$

99 KRS: 110. 43b.6-7.

100 Kun-dga’ blo-gros rgyal-mtshan-dpal bzang-po. 公哥羅古羅思監藏班藏卜 in Chinese sources. 101 Because he stayed in Dadu since 1305 and was enthroned as the Imperial Preceptor in 1315, it is certain that he and Wang Chang, who also had stayed in Dadu for a long time before banishment, had known each other.

102 Ngag dbang kun dga' bsod nams 1629: 243.

103 It is noticeable that Danyi Chenpo Zangpo Pal had been banished to 'Manzi (South China)' for fifteen years on the charge of neglect of the memorial ceremony for Phagpa, which also shows the high status of the latter during the Mongol period. He died just after this ceremony for Phagpa was finished.

104 Chang 1999: 729.

105 It is interesting to see that the last ruler of the Southern Song and previous king of Koryŏ were exiled to Tibet at the same time (Zhao Xian had stayed there for several decades before Wang Chang) under the same pretext, that is, studying Buddhism. They were moved from Sakya to Domei at the almost same time in 1323 and Wang Chang was granted amnesty while Zhao Xian was executed. While Wang Chang should know about him, neither Korean nor Tibetan sources did confirm whether the two met in Tibet. For comparing Wang Chang with Zhao Xian, see Li 2010: 417-422.

Tibetan sources referred to Koryŏ only when it was related with Tibetan Buddhism: Phagpa initiated four thousand monks and nuns (dge slong pho mo) and novice monks and nuns (dge tshul pho mo) from Nepal, India, China, Mongol, Dali, Koryǒ (ka’u li) and so on. (Ngag dbang kun dga' bsod nams 1629: 235). In the Blue Annals, there is a record on Koryŏ Buddhist in the chapter of Karmapa Rolpe Dorje (1340-1383). (Gos Lo tsa ba gZhon nu dpal (1984) [1476]: 595; Roerich (2007) [1949]: 502) In addition, the Red Annals (Deb ther dmar po), written at the end of the Mongol Empire period, mentions that during the reign of the Emperor Mingdi 明帝 (r. 57-75) 
Yi Chehyŏn's petition to the Mongol court provides a glimpse of the life of Wang Chang in Tibet. It mentioned that the way to Tibet was on risky precipices, ice and snow being piled in layers, which made the scenery in one color all the year round. Wang Chang reportedly crossed rivers in skin boats (革船), probably traditional Tibetan coracle made of yak skin. He was eating roasted barley flour (麥麨), ${ }^{106}$ namely tsampa (rtsam pa), the typical Tibetan meal and living in earthen house. In his petition Yi Chehyŏn argued that Wang Chang was Qubilai's grandson and a meritorious vassal of previous Emperors and other Koryŏ courtiers' petitions also asked for pardon, stressing Wang Chang's praying for the emperors' longevity during former five emperors' reign, which is thirty years. ${ }^{107}$

Considering that Wang Chang claimed he was away from politics and deemed it his duty to pray for the Mongol rulers, Sakya, the hometown of Tibetan Buddhism revered among the Mongol house, would be a congenial place for him to live in. As we have seen, however, he did not retire from politics at all and wanted to keep Koryǒ politics under his sway. Wang Chang did not revere Tibetan Buddhism exclusively. Koryŏ had a long Buddhist tradition and he was intimate with many Koryŏ monks. Furthermore, Wang Chang was brought up in a Confucian atmosphere, as apparent from his dialogue with Qubilai and the establishment of the Wanjuandang discussed above and his objection to the building of shrines for Phagpa saying that the latter was not comparable to Confucius. ${ }^{108}$

In 1323, Yesun Temür (r. 1323-1328), a brother of Botashiri, ascended the Yuan throne and announced a general amnesty. At first Wang Chang was moved to Hezhou 河州 (modern Linxia 臨夏, Gansu), and Yi Chehyŏn, rejoicing at the

of the Later Han Dynasty 後漢 (25-220), one Indian pandita came to China. After establishing temples and translating many sutras in China, the pandita soared to the sky to a land among the sea, so called Kaoli (ka'u li), that is Koryŏ, and passed away there. ('Tshal pa Kun dga' rdo rje 1363: 13) The Archives of China and Tibet (Rgya bod kyi yig tshang, 1434) also recorded this article following the Red Annals. (Dpal byor bzang po (1979) [1434]: 143).

106 Yi 1982 [1432]: 1. 176.

107 KRS: 110. 29b.7-30a.1; Yi 1982 [1432]: 1. 170-177.

108 While we do not know what Wang Chang thought of Tibetan Buddhism and monks, Yi Chehyŏn's writing gives us a clue: Yi wrote that as people consider the monks from Tibet as preceptor, they spoke uproariously wearing conical hats on the heads; they argued that they had the occult arts to defeat devils and crowds gathered like ants around them bringing meats and alcohol; the monks came and received gold and silk, traveling fast taking advantage of the official post station. (Yi (1982) [1432]: 84 Xin’an Post Station 新安站). Because Yi Chehyŏn was Wang Chang's closest retainer, it is safe to say that their views were similar to each other. 
news, ran to greet him there. ${ }^{109}$ Wang Chang was then reinstated but never returned to Koryǒ. ${ }^{110}$ Back in Dadu, he once more 'transferred orders' from there, appointing his favorite retainers who had been loyal to him during his exile as highest officials of Koryŏ. ${ }^{111}$ He died in Dadu in 1325, ${ }^{112}$ and his son Wang Do became the genuine ruler of Koryŏ.

However, his successors possessed even less power than him, although all of them served in the Yuan keshig before enthronement and married Mongol princesses. Koryŏ politics remained in Mongol hands until the 31st King Kongmin 恭㤵王 (r. 1351-1374) implemented the 'anti-Yuan policy' in $1356^{113}$ and the Mongols withdrew from Dadu to Mongolia in 1368.

\section{Conclusion}

This article examines the life of Wang Chang, which illustrates the impact of Mongol rule on Koryŏ politics and manifest one of the career paths of a nonMongol Imperial son-in-law.

Firstly, it shows the change of the political meaning of King's obligation of having an audience with the Qa'an. As we saw above, at the beginning of KoryŏMongol relations, during King Wŏnjong's reign, Koryŏ courtiers had intense discussion whether the king should go to have an audience with the Great Khan, which was unprecedented, while the Mongols considered it essential for showing submission. This perception gap might have resulted in 30 years of battles, before the Koreans accepted the Mongols' conditions. ${ }^{114}$ Later, however, personal audience with the Great Khan became an effective way for the Koryŏ royal members to make petitions and even Wŏnjong, at the end of his reign, tried to visit the Mongol court himself to upset the Mongol plan to install garrison farms in Koryŏ. As early as Wang Kŏ's reign, therefore, it became

109 See Ch'oe 2015 [1354]: 61.

110 When he was in exile, his son and current Koryŏ king was kept in custody in Dadu by Shidebala under various charges including that 'he had torn the edict of the emperor into pieces with his own hands.' He returned to Koryŏ in 1324. KRS: 91. 10b.7-11a.1.

111 Yi 2012: 531.

112 KRS: 34. 8a. 3. One of his Chinese friends, Zhu Derun lamented over Wang Chang's death, saying "He struggled through the path of life in all directions, without fixed place. Thereafter he was sent to the western edge and perhaps [he went there] tumbling over. Two years had passed since he came back but he reached abrupt death. Woe is me!” (Zhu 1475: 7. Memorial writing for Defender-in-chief Prince of Shen 祭太尉瀋王文).

113 For King Kongmin's complex relations with the Yuan see Lee 2016a: 259.

114 Koh 2014. 
natural that the king should visit the Mongol court in person and Wang Kŏ actually fulfilled his desires through personal meetings with Qubilai For example, he solved the false accusation against himself and received the admission of the retreat of the Mongol army and darugachis that had been stationed in Koryŏ at the beginning of Mongol-Koryŏ relations. He visited or tried to visit the Mongol court almost every year. Sometimes, the Mongol court even dissuaded him from visiting the Mongol court. ${ }^{115}$

Secondly, the biography of King Chungsŏn shows both the merit and danger of being an imperial son-in-law (güregen). As for King Ch'ungnyŏl, Wang Chang's father, his political status was greatly improved by marrying a daughter of Qubilai, and he paid respect to the relationship. On the other hand, Wang Chang was negligent of the marital relationship, which led to his abrupt dethronement. For the Mongols, marriages with the vassal states were taken not as a private coupling but as a political agreement with those states to effectively control them. Therefore, it is natural that one of the main reasons of the overthrow of Wang Chang was the negligence of his marriage relationship with Botashiri. As for Botashiri, it was important for her to produce her own offspring in order to strengthen her position in the Koryǒ court, but Wang Chang's negligence of the marital relationship made this impossible. Naturally, she strived to change the situation. Therefore, Botashiri's report that Wang Chang did not love her and prefer Chobi was a political step rather than an act of jealousy and the Mongol court sent envoys to examine it immediately.

Thirdly, Wang Chang's career shows the princely obligation and the merit of service in the Mongol keshig. As we saw above, quite a few Koryŏ princes and young noble men were serving in the keshig, and it was imperative that crown princes should serve in the keshig at the Mongol court before they became kings in Koryŏ. Wang Chang had been in the keshig before his first enthronement and entered it again after dethronement, serving another 10 years, during which he served in the keshig of Ayurbarwada and Empress Daji. This service enabled him to form close relations with the future Qa'ans Ayurbarwada and Qaishan ${ }^{116}$ that

115 However, the effects of petitions to the Mongol court were different depending on the intimacy between each Koryǒ king and the Qa'an. Wang Kŏ was a son-in-law of Qubilai which made it easy for him to achieve his goals. As for the change of meaning of Koryŏ kings' personal audience with the Qa'an, see Lee 2016b: 196-204.

116 Ijir Buqa (亦只里不花), who was on the duty of keshig in the 11th month of the first year of Ayurbarwada (1312) in the Annals of the Secretariat 秘書監志, might be another Ijir Buqa, that is, Prince of Pacifying West (Xipingwang 西平王), son of Aurugch, son of Qubilai. (The argument that this Ijir Buqa would be Wang Chang, see Masahiko 2013: 169-170) After the first Xipingwang Aurugch, his sons were divided into the Xipingwang (西平王) line and the Zhenxifujingwang (鎭西武靖王) line and it was the latter who stationed near Tibet and had 
benefitted him when they rose to the throne. Despite the diminution of their role during the middle Mongol period, the keshig undoubtedly remained influential, thanks to the proximity of the guardsmen to the ruler and his descendants. ${ }^{117}$

Fourthly, Wang Chang's biography confirms the high status of Phagpa in the whole Mongol period. Even a family member of Phagpa was punished severely if they were considered to have violated propriety regarding Phagpa. When Wang Chang was exiled to Tibet, Sakya was ruled by Phagpa's nephew, the father of the then Imperial Preceptor, Danyi Chenpo Zangpo Pal, who had been banished by Qubilai to South China for 15 years on the charge of neglect of the memorial ceremony for Phagpa. He got amnesty after many Tibetan petitions and came back to Sakya in 1298, assuming power in 1306. Even though he was the only Khön offspring to succeed to the Sakyapa throne, Qubilai did not forgive him. In this atmosphere no one in the mid-Yuan period would have been able to oppose the construction of huge Phagpa shrines. However, Wang Chang could make such an objection for it was at the beginning of reign of Ayurbarwada, when Wang Chang was said to be the Qa'an's most favorite courtier. The construction of the Phagpa shrine was one of the huge mid-Yuan projects and only Wang Chang's biography shows us the process of discussion before it was implemented, that is, no one could oppose it even though majority of courtiers were against the plan.

Lastly, the most peculiar feature of Wang Chang's career is his remotecontrol rule of his kingdom, which was unprecedented in Korean history. ${ }^{118}$ Wang Chang wielded absolute power even before his enthronement due to his noble origin, that is, a son of the Koryǒ king and a grandson of Qubilai. However, he was deposed overnight by the Mongols. When he was summoned to the Yuan capital, however, he tried to avoid leaving the capital, abdicating in favor of his son in order to stay there. ${ }^{119}$ The life of Temür Buqa (d. 1351, Ch. 帖

control over the region (Renqing 1988: 17). Therefore, while we are not sure, it is possible that Xipingwang Ijir Buqa would stay at the Mongol court at the beginning of the Ayurbarwada reign. In addition, the Koryŏsa recorded that after dethronement, Wang Chang served in keshig for 10 years (KRS: 33. 16b.7), that is 1298-1308. Furthermore, it is not plausible that Wang Chang was serving in keshig even after his restoration and abdication.

117 Melville 2006: 141.

118 Actually, Koryŏ was closer to Dadu than other political entities of the Mongol Empire. However, it is inevitable that without the king, Koryŏ politics went uncontrolled and the people suffered by paying heavy revenues to meet the King's cost of stay at the Mongol capital.

119 In assessing Wang's motive to stay in Dadu, the argument of his strong affinity with the Mongol customs does not go well with sources. Historical records testify that he did not indulge in Mongol customs. For example, according to Koryŏ sources, he did not enjoy hunting: when Wang Chang was nine years old, he criticized his father's engagement with falconry saying it was not right to going on a hunt while ordinary people were indigent. Later, when he abdicated the throne he kept just one horse in his Dadu stable and was not interested in falconry at all. (Yi 1982 [1432]: vol.2, 24). 
木兒普化, 帖睦爾普化), an iduqut of Uyghur and Prince of Gaochang 高昌王, is similar to that of Wang Chang: He also served in the keshig of Empress Daji and went back to Yingchang 永昌 to succeed to the iduqut office. However, he left for the Mongol court soon and abdicated both titles in favor of his younger brother during Tug Temür (r. 1328-1332, 文宗)'s reign. As rulers, Wang Chang and Temür Buqa stayed away from their people, which is a Mongol phenomenon. The difference between the two is that the reason why iduqut Temür Buqa abdicated the throne was that he wanted to concentrate the office of Grand Councilor of Left of Central Secretariat 中書左丞相 at the Mongol court while Wang Chang did not undertake a Mongol government service except for honorary title but continuously engaged in Koryŏ politics. This shows the difference of the political situation between the two: Office of iduqut had become largely ceremonial in nature after Qubilai lost effective control of Uyghuristan and the royal family exiled to Gansu while territorial integrity of Koryŏ was maintained under its own royal house. ${ }^{120}$

However, while Koryŏ ruling house still existed and Koryŏ kings enjoyed the high status as sons-in-law and even blood members of the Mongol royal house, the kings also faced the harsh reality that they were replaceable vassal kings whose individual kingship depended on the Mongols. Furthermore, another group tried to incapacitate him by creating a new Branch Secretariat upon Koryǒ. Therefore, it is not surprising that Wang Chang tried to avoid leaving the capital, where decisions for Empire-wide issues were made. The reason why only Wang Chang, among the Koryŏ kings, controlled over Koryŏ by staying in Dadu is because he had risen to great power in Dadu while other Koryŏ kings did not have source of power at the Mongol court. Wang Chang was recorded as an intimate of Qa'an in Ilkhanid source as well as the most favorite of the Qa'an in Chinese sources, which is confirmed by the fact that he alone could voice objection to the plan of construction of the Phagpa shrines.

In short, the unification of most of Eurasia by the Mongols brought about an unprecedented extensive movement of people. The subjugated people migrated to other regions in the Mongol realm whether it was voluntary or not, and the individual Wang Chang is a noteworthy case among these waves of displacement. In parallel with personal movement, information from one region was disseminated to another region far away in the Mongol realm, which this article examines

120 For the Uyghurs during the Mongol period, see Brose 2008. In addition, Tibetan leaders such as Sakya Pandita (Sa skya paNdita, 1182-1251) and his nephew Phagpa also stayed outside of Tibet because they were the lama of the Mongol rulers. For the Tibetan politics during the Mongol period, see Petech 1990. For the comparison of politics of Tibet and Koryŏ during Mongol period, see Tomoko 1999. 
to present a more holistic view on his life. Biography of Wang Chang demonstrates the specific case of Mongol vassal rulers, through various language sources, who made desperate effort to stay close to the center of power.

Funding: European Research Council (ERC grant agreement $n^{\circ}$ 312397: 'European Union's Seventh Framework Programme' (FP7/2007-2013)).

\section{Abbreviations}

KRS: Chŏng Inji 정인지 et al. (1451): Koryǒsa 高麗史 (History of Koryŏ).

JT: Rashīd al-Dīn Fazl Allah Hamadānī (1994) [1300-1310]: Jāmi’ al-Tawārīkh, ed. Muhammad Rūshan and Mușțafī Mūsavī. Teherān: Katībe.

\section{Bibliography}

\section{Primary Sources}

Ch'oe Hae 최해/Center for Korean History of Korea University 高麗大學校 韓國史研究所 (2015) [1354]: Cholgoch'ŏnbaek yǒkju 拙蒠千百 譯註 (An Annotated Translation of Thousands of Drafts of (hol). Seoul: Kyŏng'in Munhwasa.

Chŏng Inji 정인지 et al. (1451): Koryǒsa 高麗史 (History of Koryŏ). http://db.history.go.kr/ KOREA/item/level.do?itemld=kr\&types=r (9/15/2017).

Dpal 'byor bzang po (1979) [1434]: Rgya bod kyi yig tshang mkhas pa dga' byed chen mo 'dzam gling gsal ba'i me long (Archives of China and Tibet), vol. 1. Thim-phu, Bhutan: Kunsang Topgyel and Mani Dorji.

Gos Lo tsa ba gZhon nu dpal (1984) [1476]: Deb ther sngon po, vol. 1. Chengdu: Si khron Mi rigs Dpe skrun khang.

Gos Lo tsa ba gZhon nu dpal (1949): The Blue Annals. vol. 1. Translated by Roerich, Goerge N. Delhi: Motilal Banarsidass.

Rashīd al-Dīn Fazl Allah Hamadānī (1994) [1300-1310]: Jāmi' al-Tawārīkh. Edited by Muhammad Rūshan and Mușțafī Mūsavī. Teherān: Katībe.

Rashīd al-Dīn (1999): Jāmi ' u't-tawarikh: Compendium of Chronicles: A History of the Mongols. Translated by W. M. Thackston. Cambridge, MA: Harvard University, Dept. of Near Eastern Languages and Civilizations.

Rashīd al-Dīn (2005): K'an-ŭi huyedŭl 칸의 후예들 (Descendants of the Khan). Translated by Kim Hodong. Seoul: Sagyejŏl.

Shi Nianchang 釋念常 (2000) [1341]: “Fozu lidai tongzai 佛祖歷代通載” (Comprehensive Record of the Buddhist Patriarchs). Beijing tushuguan guji zhenben congkan 北京图书馆古籍珍本 丛刊 77: 1-476.

Song Lian 宋濂 et al., comp. (1976) [1370]: Yuanshi 元史 (The Official Yuan History). Beijing: Zhonghua Shuju. 
'Tshal pa Kun dga' rdo rje (1981) [1363]: Deb ther dmar po (The Red Annals). Beijing: Minzu chubanshe.

Yi Chehyŏn 이제현 李齊賢 (1982) [1432]: Ikchaejip 益齋集, Seoul: Minjok munhwa-ch’ujin wiwŏnhoe.

Zhu Derun 朱德潤 (1475?): Cunfuzhai wenji 存復齋文集 (Collected works of Cunfuzhai). www.eurasianhistory.com/data/upload/zhuderen.doc (9/15/2017).

\section{Secondary Sources ${ }^{121}$}

Atwood, Christopher P. (2004): Encyclopedia of Mongolia and the Mongol Empire. Facts on File. Biran, Michal (1997): Qaidu and the Rise of the Independent Mongol State in Central Asia. Richmond, Surrey: Curzon.

Brose, Michael C. (2008): "People in the Middle: Uyghurs in the Northwest Frontier Zone". In: Battlefronts Real and Imagined: War, Border, and Identity in the Chinese Middle Period. Edited by Don J. Wyatt. New York: Palgrave Macmillan, 253-289.

Chang, Dong yig 장동익 (2011): “Kwonhan'gong-ŭi saeng’ae-wa haengjŏk” 권한공(權漢功)의 생애(生涯)와 행적(行蹟) (The Life and Career of Kwon Han-gong). Taegu sahak 104: 61-98.

Ch’oe, Yunjŏng 최윤정 (2015): “14 segich’o (1307-1323) Wŏn chŏngguk-kwa Koryō” 14 세기 초 (1307-1323) 원 정국과 고려 (The Political Situation of the Yuan and Koryŏ). Yeŏksa hakbo 226: 287-320.

Chang, Dong-yig 장동익 (1999): “Shinjaryo-rŭl t’onghae bon Ch'ungsŏnwang-ŭi chaewŏn hwaltong” 新資料总 통해 본 忠宣王의 在元 活動 (King Ch’ungsŏn's Activity in the Yuan Seen in New Sources). Yǒksa gyoyuk nonjip 23/24: 703-745.

Chen, Qingying 陈庆英 (1992): Yuanchao dishi basiba 元朝帝师八思巴 (The Imperial Preceptor of the Yuan Dynasty, Phagpa). Beijing: Zhongguo Zangxue chubanshe.

Hidehiro, Okada 岡田英弘 (1959): “Gan no shino to ryoyo kosho” 元の潘王と遼陽行省 (Prince of Shen and Liaoyang Province of the Yuan). Chosen gakuho 14: 533-543.

Kim, Doyŏng 김도영 (2011): “Man'gwŏndang-gwa Chemigidǒkdang-e taehan chaegŏmt'o” 萬卷 堂과 濟美基德堂에 대한 재검토 (A Reconsideration of Man'gwŏn-dang and Jemigidǒkdang). Yŏksa hakbo 210: 59-95.

Kim, Hodong 김호동 (2007): Mongoljeguk-kwa Koryŏ: K’ubilai chŏnggwŏn-ŭi t'ansaeng-gwa Koryŏ-ŭi chŏngch'ijŏk wisang 몽골제국과 고려: 쿠빌라이 정권의 탄생과 고려의 정치적 위상 (The Mongol Empire and Koryŏ: The Rise of Qubilai and the Political Status of the Koryŏ Dynasty). Seoul: Seoul National University Press.

Kim, Hyewon 김혜원 (1989): “Yǒ-Wŏn wangsil t’onghon-ŭi sŏngnip-gwa t’ǔkjing” 麗元王室通婚 의 成立과 特徵 (A Study on the Foundation and Characteristics of the Koryo-Mongol Royal Marriage). Yidae-sawŏn 24/25: 163-212.

Kim, Hyŏnra 김현라 (2008): “Koryŏ Ch’ungnyŏrwangbi Chegukdaejang gongju-ŭi wisang-gwa yŏkal” 고려 충렬왕비 齊國大長公主의 위상과 역할 (The Social Standing and Political Role of Princess Jegukdaejang). Chiyŏk-kwa Yŏksa 23: 71-99.

Kim, Kwangch’ŏl 김광철 (1996): “14 segich’o Wŏn-ŭi chŏng’guk tonghyang-gwa Ch'ungsŏnwang-ŭi T’obŏn yubae” 14세기 초 元의 政局 동향과 忠宣王의 吐蕃 유배 (The

121 English translation of title of non-English source as suggested by the original author. 
Political Situation of the Yuan and King Chu'ngsŏn's exile to Tibet). Han'guk Chungsesa Yŏn'gu 3: 290-343.

Koh, Myung-Soo 고명수 (2014): “Mongor-ŭi poksok insik-kwa yŏmong kwan'gye” 몽골의 ‘복속’인식과 여몽관계 (Mongol Recognition of ‘Subjection' and the Relations between the Mongols and Goryŏ). Hanguk sahakbo 55: 43-79.

Koh, Myung-Soo 고명수 (2015): “Chungnyŏrwang-dae Kelingkou ch’ulsin kwanwŏn - MongolKoryŏ t'onghon kwan'gye-ŭi han tanmyŏn” 충렬왕대 怯憐口(怯怜口) 출신 관원 - 몽골고려 통혼관계의 한 단면 (Officials from Ke-ling-kou during King Chungryeol's Regime - An Aspect of the Intermarriage Relationship between Mongol and Goryeo). Sahak Yŏn'gu: The Review of Korean History 118: 233-270.

Lee, Ik-Joo 이익주 (2009): “Koryŏ-Mongol kwan'gyesa yŏn'gu sigak-ŭi chaegŏmt’o” 고려-몽골 관계사 연구 시각의 검토 (Overview Investigation on the History of Goryeo-Mongol Relationship). Han'guk Chungsesa Yŏn'gu 27: 5-43.

Lee, Jung-Shin 이정신 (2014): “Koryŏ hugi-ŭi yŏkkwan” 高麗後期의 譯官 (Official Interpreters in the Late Goryeo Dynasty). Han'guk Chungsesa Yŏn'gu 38: 373-403.

Lee, Mee-Souk 이미숙 (2015): “Wŏn kansŏpki yŏkgwan-e kwanhan ilgoch’al” 원(元) 간섭기 역관에 관한 일고찰 (A study on? Interpretation officers? in Yuan Dynasty interference period). Hanguk sasang'gwa munhwa 79: 197-228.

Lee, Myŏng-mi 이명미 (2003): “Koryǒ-Wŏn wangsil t’onghon-ŭi chŏngch’i jŏk ŭimi” 고랴·원 왕실 통혼의 정치적 의미 (The Political Nature of the Royal Marriages Arranged between the Royal Families of Koryŏ and the Mongol Empire). Han'guksaron 49: 7-85.

Lee, Myŏng-mi 이명미 (2013): “Monggol poksokki Koryŏ kugwang wisang-ŭi han ch’ŭngmyŏn” 몽골 복속기 고려국왕 위상의 한 측면 (Mongol's recognition of Goryeo kingship in Subjugation period). Dong'guksahak 54: 125-171.

Lee, Myŏng-mi 이명미 (2016a): 13-14segi Koryŏ-Mongol kwan'gye yŏn'gu 13-14세기 고려 몽골 관계 연구 (Research on Relations between Koryŏ and the Mongols in the $13^{\text {th }}$ and $14^{\text {th }}$ Centuries). Seoul: Hye'an.

Lee, Myŏng-mi (2016b): “Koryŏ kugwang-ŭi Mongol ipcho yangsang-kwa kugwangkwŏn-ŭi chonjae yangtae" 고려국왕의 몽골 入朝양상과 국왕권의 존재양태 (The Patterns and Meanings of Goryeo Kings' Attendance at the Mongolian Royal Court). Han'guk Chungsesa Yŏn'gu 46: 187-220.

Lee, Kang Hahn 이강한 (2008): “Koryŏ Ch’ungsŏnwang-ŭi chŏngch’i kaehyŏk-kwa Wŏn-ŭi yŏnghyang” 고려 충선왕의 정치개혁과 元의 영향 (Koryŏ King Chungsŏn-wang’s Political Reforms and their Yuan-related Aspects). Hanguk munhwa 43: 267-300.

Li, Qinpu 李勤璞 (2010): “Zuqun zhengzhi yu diguo de yitihua: Gaoli yu Xizang fojiao guanxi yanjiu (xu)” 族群政治與帝國的一體化: 高麗與西藏佛敎關係研究 (續) (Ethnic Politics and Imperial Unity: Research on the Relations between Koryŏ and Tibetan Buddhism). Liaoningsheng bowuguan guankan 5: 404-432.

Li, Zhi'an 李治安 (2003): Yuandai zhengzhi zhidu yanjiu 元代政治制度研究 (Research on the Political System of the Yuan Dynasty). Beijing: Renmin chubanshe.

Ma, Xiaolin 馬曉林 (2013): “Yuandai basiba dishi jisi yanjiu” 元代八思巴帝师祭祀研究 (A Study on the Imperial Ritual of Sacrifice to "Phags-pa in the Yuan Dynasty)”. Beida shixue 北大史学 18: 81-103.

Masahiko, Morihira 森平 雅彦 (1998): “Buma korai kokuo i no seiritsu: gancho ni okeru koraio no chii ni tsuite no yobiteki kosatsu” 駙馬高麗國王位の成立: 元朝における高麗王の地位 についての豫備的考察 (The Establishment of the Title 'The Imperial Son-in-law King of 
Koryŏ’: Preliminary Research on the Status of King of Koryŏ under the Yuan). Toyo Gakuho 79.4: 343-373.

Masahiko, Morihira 森平 雅彦 (2008): “Korai oke to mongoru kozoku no tsukon kankei ni kansuru oboegaki” 高麗王家とモンゴル皇族の通婚關係に關する覺書 (Memorandum on the Royal Marriages between Koryŏ and the Mongol Imperial House). Toyoshi Kenkyu 67.3: 363-401.

Masahiko, Morihira 森平 雅彦 (2013): Mongoru haken sita no korai モンゴル覇権下の高麗 (Koryŏ under the Mongol Hegemony). Nagoya: Nagoya University Publication.

May, Timothy (2016): Commercial Queens: Mongol Khatuns and the Silk Road. Journal of the Royal Asiatic Society 26: 1/2: 89-106.

Melville, Charles (2006): “The Keshig in Iran: The Survival of the Royal Mongol Household”. In: Beyond the Legacy of Genghis Khan. Edited by Linda Komaroff. Leiden/Boston: Brill, 135-165.

Park, Hyunhee 박현희 (2016): “Soju-ǔi hŭnggi-Mongol sigi (1206-1368) ‘Chung’guk’ esŏ hanbando’ero chŭngnyu kisul-ŭi chŏnp’a” 燒酒의 흥기-몽골 시기 (1206-1368) ‘중국’에서 한반도에로 증류기술의 전파 (The Rise of Soju: The Transfer of Distillation Technology from 'China’ to Korea during the Mongol Period (1206-1368)). Chung'ang Asia Yŏn'gu 21.1: 69-93.

Petech, Luciano (1990): Central Tibet and the Mongols: the Yüan-Sa-skya period of Tibetan history. Rome: Istituto Italiano per il Medio ed Estremo Oriente.

Petech, Luciano (1993): “'P’ags pa”. In: In the Service of the Khan. Edited by Igor de Rachewiltz, Hok-lam Chan, Hsiao Ch'i-ch'ing and Peter W Geier. Wiesbaden: Harrassowitz Verlag, 646-654.

Pyŏn, Dongmyŏng 변동명 (2003): “Ch’ungsŏnwang-gwa mansŭnghoe” 忠宣王과 萬僧會 (King Ch'ungsŏn and Buddhist Ceremony with Ten Thousand Monks). Minjok munhwa nonchong 21: 185-209.

Renqing, Zhaxi 仁慶札西 (1988): “Xipingwang yu tufan de guanxi 西平王與吐蕃的關係 (The Relations between Prince of Xiping and Tibet)”. Zhongyang minzu xueyuan xuebao 中央民 族學院學報 1: 16-18.

Tomoko, Otosaka 智子 乙坂 (1999): “Gancho no taigai seisaku - Korai-Chibeto kuncho e no shogu ni miru naihu taisei” 元朝の対外政策 - 高麗・チベット君長への處遇に見るく內府 > 体制 (Foreign policy in the Yuan Dynasty- Summoning the Foreign Kings and Hostages of Princes). Sikyo 史境 38/39: 30-53.

Vermeersch, Sem (2008): The Power of the Buddhas: The Politics of Buddhism during the Koryǒ Dynasty (918-1392). Cambridge MA: Harvard University Press.

Yi, Sŭnghan 이승한 (1988): “Koryŏ Ch’ungsŏnwang-ŭi Simyangwang p’ibong-gwa chaewŏn chŏngch'ihwaldong” 고려 忠宣王의 瀋陽王 被封과 在元 정치활동 (The Investiture of Koryŏ King Ch'ungsŏn Shenyangwang and his Political Activities in the Yuan). Chŏnnam sahak 2: $1-51$.

Yi, Sŭnghan 이승한 (2012): Honyŏrwang, Ch’ungsŏnwang 혼혈왕, 충선왕 (Half-Blooded King, King Ch’ungsŏn). Seoul: Phureŭn Yŏksa.

Zheng, Xiyuan 鄭錫元 (2011): “Kaoli dui menggu wenhua de "shourong” yu paichi - yi “menggu feng” zai Gaoli xingshuai weili 高丽对蒙古文化的“受容”与排斥一以“蒙古风”在高丽兴衰为 例 (The Acceptance and exclusion of Mongolian Culture in Korea: On the Rise and Decline of “Mongolian Fashion” in Korea). Journal of Guizhou University for Nationalities 127.3: 50-57. 